\title{
NEW RECORD OF THE GENUS Buluka de Saeger (Hymenoptera: Braconidae: Microgastrinae) WITH DESCRIPTION OF A NEW SPECIES FROM VIETNAM
}

\author{
Khuat Dang Long \\ Institute of Ecology and Biological Resources, VAST, khuatdanglong@iebr.ac.vn
}

\begin{abstract}
Buluka de Saeger, 1948, is a rare genus of the subfamily Microgastrinae, in this paper one new species of the genus, Buluka vuquangensis Long, sp. n., is described and illustrated. Additionally, the genus Buluka de Saeger is recorded for the first time for Vietnam.
\end{abstract}

Keywords: Braconidae, Microgastrinae, Buluka, new record, new species, Vietnam.

\section{INTRODUCTION}

Buluka de Saeger, 1948 was originally described by de Saeger (1948) [6] and placed in the subfamily Sigalphinae (de Saeger, 1948) on the basis of a carapace-like gaster, a character known to occur convergently in a wide range of braconid subfamilies. However, Nixon (1965) [13] correctly recognized the form of the wing venation and antennae, among other characters, and placed the genus in the Microgastrinae. Since then, except for the works of Mason (1981) [12], Chou (1985) [5] and Austin (1989) [3], the genus has received no attention.

The genus Buluka de Saeger until recently was very rarely collected, however, intensive collecting techniques, such as the use of Malaise traps, have yielded a significant number of specimens, which now allow for more critical assessment of this genus.

Originally described from two specimens collected at Rutshuru, Belgian Congo (now Zaire) (de Saeger, 1948), B. straeleni was subsequently also recorded from South Africa (Nixon, 1965) [13]. The study, in which Chou (1985) [5] described a second species from Taiwan, revealed further non-African species. Further, Austin (1989) [3] described five species from the Indo-Australian region and gave a key to seven known species, in fact the present distribution of the genus strongly indicates an Indo-Pacific centre of radiation.

Most species of the Microgastrinae are parasitoids of Lepidoptera hosts, that include different families, as far as now the only exception of Apanteles (Choeras) gielisi van
Achterberg, 2003 recorded from Trichoptera was confirmed as non-Lepidoptera hosts of Microgastrinae (van Achterberg, 2003) [2]. The genus Buluka de Saeger is recorded for the first time for Vietnam and one new species is described. There is no information of the host of Buluka vuquangensis Long, sp. $\mathrm{n}$. but likely it is a larva of Lepidoptera.

\section{MATERIALS AND METHODS}

Specimens studied are deposited in the Collection of the Institute of Ecology \& Biological Resources (IEBR) and Vietnam National Museum of Nature (VNMN) at $\mathrm{Ha}$ Noi, assembled by the author during numerous expeditions in Vietnam.

Terminology used in this paper follows van Achterberg (1988) [1], sculpture terms are based on Harris (1979) [5]; for a key to the genera of the subfamily Microgastrinae see Nixon (1965) [13], for dentification of the genus Buluka see Mason (1981) [11], for additional references and data to the genus Buluka see Yu et al. (2012) [14]; for diagnosis of Buluka see Austin (1989) [3]. The measurements were made with a binocular microscope (Olympus ${ }^{\circledR}$ SZ40), photographic images were made with a Canon G15 camera attached to a Olympus ${ }^{\circledR}$ SZ61 binocular microscope at IEBR. Mic. + number: code number indexing for specimens of the Microgastrinae in the collection. Abbreviations used in this paper are as follows: $\mathrm{OD}=$ diameter of posterior ocellus; $\mathrm{OOL}=$ ocular-ocellar line; $\mathrm{POL}=$ postocellar line $; \mathrm{NC}=$ North Central; NP $=$ National Park; MT $=$ Malaise trap. The 
holotype and paratype are kept in the Vietnam National Museum of Nature (VNMN) (Ha Noi, Vietnam).

\section{RESULTS AND DISCUSSION}

\section{Systematics}

Buluka de Saeger, 1948 (Figs 1-10)

Buluka de Saeger, 1948: 64. Type species, by original designation, Buluka straeleni de Saeger, 1948. Nixon, 1965: 265; Mason, 1981: 121; Austin, 1989: 150; Austin \& Dangerfield, 1992: 17.

\section{Diagnosis}

The most distinguishing feature of Buluka is its gastral carapace, which is more or less formed by the fusion of second and third metasomal terigites, and fourth and following tergites retracted. This feature, although found throughout the Braconidae in various forms is rare within the Microgastrinae. The formed gastral carapace is known only in Fornicia Brullé, the basimacula species-group of Diolcogaster Ashmead and to a lesser degree in Deuterixys Mason and Pholetesor Mason.

Head medium-sized, eye setose (figs 3, 4, 9). Propleuron with a small apical lobe overlapping the pronotum. Scutellum and scutum densely rugose or reticulate rugose (fig. 5). Propodeum rugose, with a median carina; metanotum closely appressed to scutellum; apical band of scutellum broadly interrupted by a rugose area. Hind coxae large, extending past the posterior margin of second tergite. Vein r-m of fore wing present, areolet large, quadrangular (fig. 10); vannal lobe convex and hairy. In dorsal view, first-third metasomal tergites occupying entire dorsal surface of abdomen and all rugose; first tergite with a median sharp groove; second tergite without medial area (fig. 6); second metasomal suture comparatively wide; third metasomal suture more or less fused. Hypopygium short and evenly sclerotized; ovipositor short, sheath setose only at apex and with a pair of large apical spatulate sensilla.

\section{Checklist and distribution of Buluka species}

Buluka achterbergi Austin, 1989; from Malaysia; Malaysia-Peninsular.

Buluka collessi Austin \& Dangerfield, 1992; from Australia; Australia-Queensland.

Buluka vuquangensis Long, sp. n.; from Vietnam.

Buluka huddlestoni Austin, 1989; from Solomon Islands.

Buluka noyesi Austin, 1989; from India.

Buluka orientalis Zhou, 1985; from China; China-Taiwan.

Buluka straeleni De Saeger, 1948; from Cameroon; Democratic Republic of Congo; South Africa.

Buluka taiwanensis Austin, 1989; from China; China-Taiwan.

Buluka townesi Austin, 1989; from Malaysia; Malaysia-Peninsular.

The new species can be inserted before running-on the fifth couplet in the key by Austin (1989) as follows:

a. Scutellum recticulate-rugose (Fig. 10 in Austin, 1989) or rugose-punctate; anterior margin of second metasomal tergite 2 with course longitudinal carinae, rest of second tergite reticulaterugose (Fig. 6 in Austin, 1989); tegula brown or dark brown

b. Scutellum areolate-rugose (Fig. 5); second metasomal tergite 2 sparsely carinate entirely (Fig. 6); tegula yellow B. vuquangensis $\mathrm{sp} . \mathrm{n}$.

Buluka vuquangensis Long, sp. n. (Figs 1-10)

Material. Holotype, $q$ (VNMN), Mic.1215, NC Vietnam: Ha Tinh, Vu Quang NP, forest, 04.X.2009, KD Long; paratype , 10 त (VNMN), ibid. but 29.X.2009, KD Long.
Description. Holotype, $q$ (fig. 1). Body length $2.6 \mathrm{~mm}$, fore wing length $2.6 \mathrm{~mm}$, antenna $2.5 \mathrm{~mm}$.

Head. Third antennal segment 1.2 times as long as fourth (11:9); seventh antennal segments 4.0 times longer than wide $(8: 2)$; 
median width of face 0.7 times length of face and clypeus combined (11:16); mean face width 0.4 times head width (11:31); clypeus slightly concave; distance between tentorial pits 2.3 times distance between pits and eyes (7:3); in dorsal view, height of eyes 2.8 times as high as temple (14:5); in lateral view width of eye 1.3 times as long as temple (9:7); ocelli in very low triangle, anterior tangent of posterior ocelli crossing anterior ocellus medially (fig. 3), POL 0.8 times as long as OOL; POL:Od:OOL $=$ 5:2:6; distance between front and hind ocelli 0.25 times as long as OOL (1.5:6) (fig. 3). Face smooth, sparsely setose (fig. 4); frons, vertex and temple smooth.

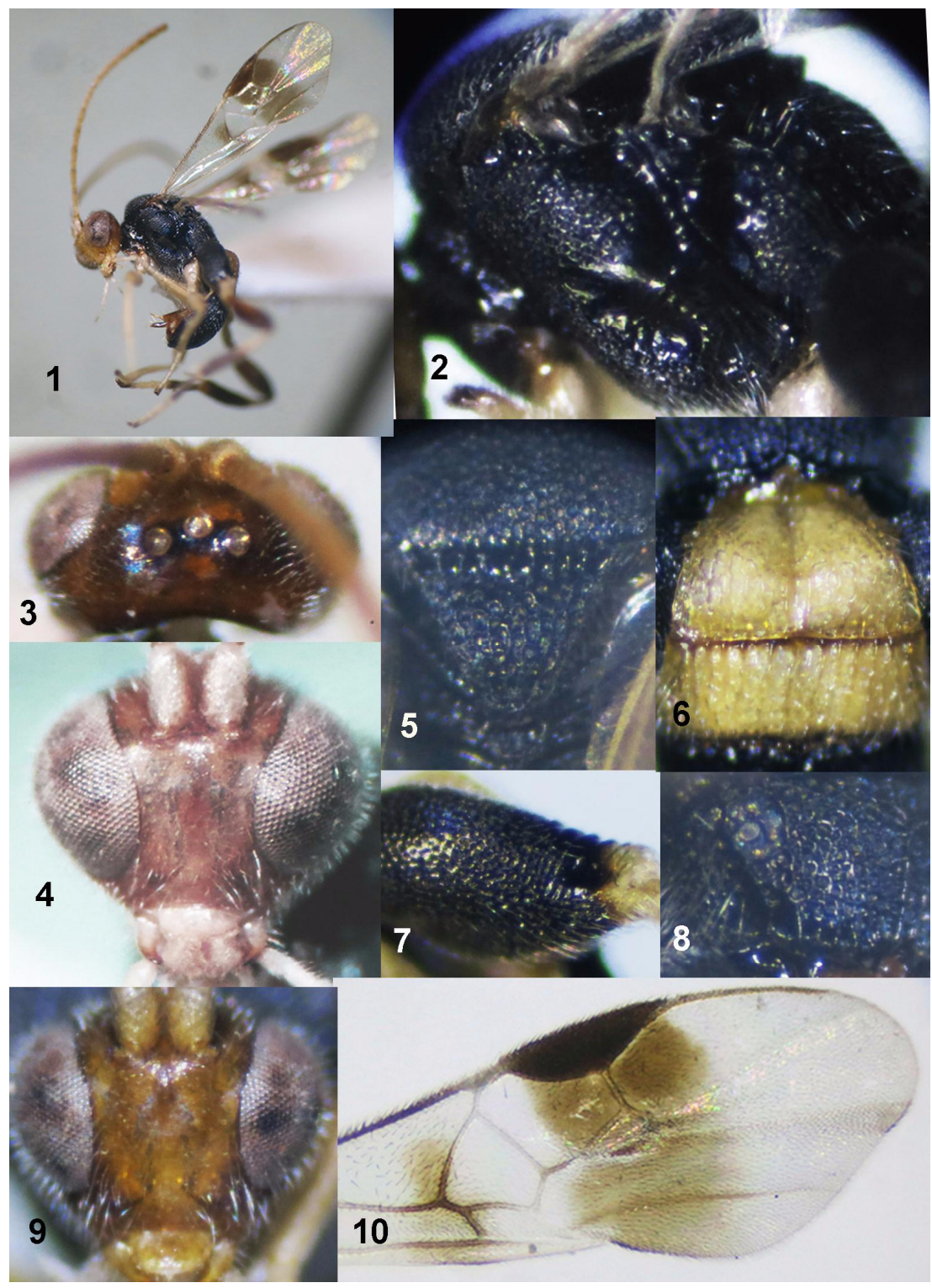

Figures 1-10. Buluka vuquangensis $\mathrm{sp} . \mathrm{n}$.

1. Female (habitus); 2. Mesopleuron; 3. Head (dorsral view); 4. Head (frontal view); 5. Scutellum; 6. First and second metasomal tergites; 7. Hind coxa (dorsal view); 8. Propodeum (left side); 9. Head (frontal view, male); 10. Fore wing. 
Mesosoma. Length of mesosoma 1.45 times as long as high (45:31); pronotal trough shiny, crenulate; mesopleuron reticulate-rugose dorsoanteriorly and ventrally; precoxal sulcus groove-like, wide and smooth (fig. 2); mesoscutum reticulate-rugose; in lateral view, scutellum convex, distinctly higher the level of mesoscutum; sutellar sulcus deep, with eight medial carinae (fig. 5); scutellum areolaterugose; propodeum with medial carina, reticulate-rugose; propodeal spiracle rather small, round, surrounded by distinct carinae (fig. 8).

Wings. Fore wing (fig. 10), pterostigma 3.1 times as long as wide (22:7) and 1.1 times vein 1-R1 (22:20); parastigma 1.3 times longer vein 1-SR (4:3); vein $r$ of fore wing arising after middle of pterostigma (fig. 10); vein r 0.7 times as long as vein 2 -SR and 1.7 times vein 3 -SR (r:2-SR:3-SR=5:7:3); vein 1-CU1 as long as cua and 0.4 times vein 2-CU1 (3:8); fore vein 2$\mathrm{SR}+\mathrm{M}$ as long as vein $\mathrm{r}$ and 1.25 times vein $\mathrm{m}$ cu (5:4). Hind wing: vein $\mathrm{M}+\mathrm{CU} 0.8$ times vein 1-M (12:15); M+CU:1-M:1r-m=12:15:3.

Legs. Hind coxa large, largely rugose but strongly transversely striate dorso-apically (Fig. 7). Length of hind femur:tibia:basitarsus:tarsus= 32:41:19:44; length of hind femur, tibia and basitarsus 3.6, 5.9 and 4.7 times as long as their width, respectively; inner hind tibial spur 0.5 times as long as basitarsus (10:19).

Metasoma. Posterior rim of gaster not indented; first tergite with median smooth groove (fig. 6), 0.6 times as long as apical width (16:26), areolate-rugose; second metasomal suture comparatively wide, crenulate (fig. 6); third metasomal suture fused but more or less crenulated; second and basal half of third metasomal tergites with sparse longitudinal carinae, apical half of third tergite largely punctate.

Colour. Head, antennae yellow; palpi ivory; mesonotum black; fore and middle legs ivory, except telotarsus brownish; hind coxa black; hind trochanters and trochatellus ivory; hind femur yellow basally, dark brown apically; hind tibia and basitarsus ivory at extreme base, dark brown apically; hind second-fourth tarsus ivory; telotarsus brown; hind spurs ivory; tegula yellow; pterostigma and vein 1-R1 yellowish brown; the rest veins whitish yellow; fore wing with large infuscated band beneath pterostigma, covering second submarginal cell and extending down to lower margin (fig. 10); area around vein 1-M basally, 1-CU1 and cu-a infuscated; two fisrt metasoma; tergites yellow, third tergite black; ovipositor sheath dark brown.

Etymology: Named after the type locality: Vu Quang National Park.

\section{Host: Unknown.}

Notes: Male differs from female by moderate broad face, median width of face 0.8 times length of face and clypeus combined (13:17); (fig. 9) [face of female distinctly narrowed medially (fig. 4)]; scutellar sulcus with 7 carinae; fore wing with larger and darker brownish band; hind femur largely brown basally; first metasomal tergite yellow but dark brown at extreme apex.

Buluka vuquangensis is similar to Buluka noyesi Austin, 1989, from India but differs from the later by having scutellum areolate-rugose; second metasomal tergite with sparse longitudinal carinae entirely; in lateral view third metasomal tergite not indented above rim; head yellow (black in noyesi). The new species is also close to Buluka townesi Austin, 1989; from Malaysia but differs by face of female narrowed medially, mean face width 0.4 times head width; scutellum areolate-rugose; propodeal spiracle round, small; basitarsus black.

Acknowledgements: This research is funded by the Vietnam National Foundation for Science and Technology Development (NAFOSTED) under grant number 106.15-2012.62. The author thanks the anonymous reviewer and the editor for the helpful comments on the manuscript.

\section{REFERENCES}

1. Achterberg van C., 1988. Revision of the subfamily Blacinae Foerster (Hymenoptera, Braconidae). Zoologische Verhandelingen Leiden, 249: 1-324.

2. Achterberg van C., 2003. Apanteles 
(Choeras) gielisi spec. nov. (Hymenoptera: Braconidae: Microgastrinae) from The Netherlands and the first report of Trichoptera as host of Braconidae. Zoologische Mededelingen Leiden, 76(5): 53-60.

3. Austin A. D., 1989. Revision of the genus Buluka de Saeger (Hymenoptera: Braconidae: Microgastrinae). Systematic Entomology, 14: 149-163.

4. Austin A. D., Dangerfield P. C., 1992. Synopsis of Australasian Microgastrinae (Hymenoptera: Braconidae), with a key to genera and description of new taxa. Invertebrate Taxonomy, 6(1): 1-76.

5. Chou L.Y., 1985. A new species of Buluka (Hymenoptera: Braconidae) from Taiwan. Chinese Journal of Entomology, 5: 85-88.

6. De Saeger H., 1948. Cardiochilinae et Sigalphinae (Hymenoptea: Apocrita) Fam. Braconidae., Exploration du Parc National Albert. Mission G.F. de Witte, 53: 1-272.

7. Harris R. A., 1979. A glossary of surface sculpturing. Occasional Papers in Entomology, California Department of Food and Agriculture, 28: 1-33.

8. Khuat Dang Long, 2010. Five new species of the genus Apanteles (Hymenoptera: Braconidae: Microgastrinae) from Vietnam. Tap chi Sinh hoc, 32(4): 69-79.
9. Khuat Dang Long, Achtererg van C., 2008. Two genera and one species newly recorded with description of five new species of the subfamily Microgastrinae (Hymenoptera: Braconidae) from Vietnam. Tap chi Sinh hoc, 30(3): 78-87.

10. Khuat Dang Long, Belokobylskij S. A., 2003. A preliminary list of the Braconidae (Hymenoptera) of Vietnam. Russian Entomological Journal, 12(4): 385-398.

11. Khuat Dang Long, Achtererg van C., 2014. An additional list with new records of braconid wasps of the family braconidae (Hymenoptera) from Vietnam. Tap chi Sinh hoc, 36(4): 397-415. DOI: 10.15625/0866$7160 / v 36 n 4.5979$.

12. Mason W. R. M., 1981. The polyphyletic nature of Apanteles Foerster (Hymenoptera: Braconidae): A phylogeny and reclassification of Microgastrinae. Mem. Entom. Soc. Canada, 115: 1-147.

13. Nixon G. E. J., 1965. A reclassification of the tribe Microgasterini (Hymenoptera: Braconidae). Bull. Br. Mus. nat. Hist. Entomology, Suppl., 2: 1-284.

14. Yu D. S., Achterberg van K., Horstmann K., 2013. Ichneumonoidea 2012 (Biological and taxonomical information), Taxapad Interactive Catalogue, Ottawa, Canada. www.taxapad.com.

\title{
GHI NHẬN MỚI GIỐNG Buluka de Saeger (Hymenoptera: Braconidae: Microgastrinae) VÀ MÔ TẢ MỘT LOÀI MỚI CHO KHOA HỌC Ở VIỆT NAM
}

\author{
Khuất Đăng Long
}

Viện Sinh thái và Tài nguyên sinh vật, Viện Hàn lâm KH \& CN Việt Nam

\section{TÓM TẮT}

Buluka de Saeger, 1948 là một trong các giống ong rất hiếm gặp thuộc phân họ Microgastrinae (Hymenoptera: Braconidae). Đây là lần đầu tiên giống Buluka được ghi nhận cho khu hệ của Việt Nam. Cho đến nay mới chỉ có 7 loài được ghi nhận từ khu hệ vùng Indo-Pacific và 1 loài từ khu hệ Afrotropical. Bài báo này mô tả một loài mới cho khoa học, Bulula vuquangensis Long, sp. n., từ khu hệ ong ký sinh của Việt Nam. Sự khác nhau của loài mới với loài Buluka noyesi Austin, 1989 của Ân Độ và loài B. townesi Austin, 1989 
của Malaysia đã được so sánh. Danh sách và phân bố của 8 loài đã biết thuộc giống Buluka cũng được trình bày trong bài báo.

Các loài thuộc giống Buluka có kích thước cơ thể nhỏ, chưa có thông tin về vật chủ của các loài thuộc giống này cũng như của loài mới từ khu hệ của Việt Nam, tuy nhiên, dựa theo thông tin vật chủ của nhiều loài khác thuộc phân họ Microgasrinae, có khả năng vật chủ của loài mới này là sâu non các loài côn trùng thuộc họ cánh vảy.

Từ khóa: Braconidae, Microgastrinae, Buluka, ghi nhận mới, loài mới, Việt Nam.

Ngày nhận bài: 20-8-2015 